\title{
Conservation and viability of refrigerated platelet-rich plasma from New Zealand rabbits
}

\section{Conservação e viabilidade de plasma rico em plaquetas refrigerado de coelhos Nova Zelândia}

\author{
Lucas Vilela Perroni Silva ${ }^{1 *}$; Duvaldo Eurides ${ }^{2}$; \\ Marina Greco Magalhães Guerra de Andrade ${ }^{3}$; Marcelo Carrijo da Costa \\ Vinicius Candido Ferreira ${ }^{5}$; Marina de Oliveira Silva ${ }^{5}$; Ednaldo Carvalho Guimarães ${ }^{6}$
}

\begin{abstract}
Fifteen male New Zealand rabbits were used in this study, with the aim of storing their platelet-rich plasma (PRP) for 30 days at $4-6{ }^{\circ} \mathrm{C}$ to investigate its conservation and viability during this period. Thirty samples of PRP were prepared and sorted into three equal groups (G1, G2, and G3), and every three days a sample was taken out for evaluationof the number of platelets, mean platelet volume (MPV), $\mathrm{pH}$ of the plasma, aggregation post addition of calcium thromboplastin, and for the presence of bacterial and fungal contamination. Results suggested that, for the number of platelets, there was no linear relationship over time. However, when comparing the number of platelets pre-storage to that post-storage, a statistical difference was observed. The hemogram MPV variables, pre and post-storage, also did not relate with time however, there was a statistical difference between the MPV of hemogram and MPV pre-storage, and between MPV pre-storage and MPV post-storage. From the $\mathrm{pH}$ evaluation, no influence of time on the variables was found, but statistical differences were found in the samples after storage between 30 and 6 days, 30 and 24 days, and 30 and 27 days. Platelet aggregation occurred within twenty seconds in all samples, independent of storage time. There was no growth of bacteria or yeast in any sample; however, mold growth occurred in the samples stored for 21 days from G1 and G3. It can be concluded that the PRP of rabbits can be stored in $4-6{ }^{\circ} \mathrm{C}$ refrigeration for up to 18 days and still maintain the number of platelets, with no significant $\mathrm{pH}$ alteration or bacterial or fungal contamination. Key words: Platelet aggregation. Platelet concentrate. Storage.
\end{abstract}

\section{Resumo}

Quinze coelhos machos da raça Nova Zelândia foram utilizados neste experimento, com a finalidade de armazenar o plasma rico em plaquetas (PRP) durante 30 dias a $4-6^{\circ} \mathrm{C}$ para investigar a sua conservação e viabilidade durante este período. Trinta amostras de PRP foram preparadas e divididos em três grupos iguais (G1, G2 e G3), e de três em três dias foi retirada uma amostra para avaliação do número de plaquetas, volume plaquetário médio (VPM), pH do plasma, agregação após adição de tromboplastina cálcica, e para a presença de contaminação bacteriana e fúngica. Os resultados sugerem que, para o

1 Discente do Curso de Doutorado do Programa de Pós-Graduação em Ciências Veterinárias, Universidade Federal de Uberlândia, PPGCV/UFU, Uberlândia, MG, Brasil. E-mail: lperronivet@gmail.com

2 Prof., PPGCV/UFU, Uberlândia, MG, Brasil. E-mail: duvaldo@ufu.br

3 M.e em Ciências Veterinárias, PPGCV/UFU, Uberlândia, MG, Brasil. E-mail: vetmarina@yahoo.com.br

4 Residente em Cirurgia de Pequenos Animais, Programa de Residência em Medicina Veterinária, UFU, Uberlândia, MG, Brasil. E-mail: marcelocarrijo@hotmail.com

5 Médicos Veterinários, UFU, Uberlândia, MG, Brasil. E-mail: vinicius_candido18@hotmail.com; nininha_oli@hotmail.com

6 Prof., Faculdade de Matemática, UFU, Uberlândia, MG, Brasil. E-maili: ecg@ufu.br

Author for correspondence 
número de plaquetas, não houve uma relação linear com o tempo. No entanto, quando se compara o número de plaquetas pré-armazenamento com o pós-armazenamento, foi observada diferença estatística. As variáveis VPM no hemograma, pré e pós-armazenamento, também não se relacionou com o tempo, porém, houve diferença estatística entre o VPM do hemograma e pré-armazenamento, e entre VPM pré-armazenamento e pós-armazenamento. A partir da avaliação do $\mathrm{pH}$, não houve influência do tempo sobre as variáveis, porém foram encontradas diferenças estatísticas nas amostras após o armazenamento entre 30 e 6, 30 e 24, e 30 e 27 dias. A agregação de plaquetas ocorreu no prazo de vinte segundos, em todas as amostras, independente do tempo de armazenamento. Não houve crescimento de bactérias ou fungos em qualquer amostra; no entanto, o crescimento de fungos ocorreu nas amostras armazenadas durante 21 dias dosgrupos G1 e G3. Pode-se concluir que o PRP de coelhos pode ser armazenado sob refrigeração $4-6^{\circ} \mathrm{C}$ por até 18 dias por manter o número de plaquetas, sem alteração significativa do $\mathrm{pH}$ ou contaminação bacteriana ou fúngica.

Palavras-chave: Agregação plaquetária. Armazenamento. Concentrado de plaquetas.

\section{Introduction}

Platelet-rich plasma (PRP), which is a platelet concentrate of a small volume of plasma, is obtained after centrifugation of whole blood samples via the density gradient technique (VANAT et al., 2012). Platelet concentrate has been widely used in human and veterinary medicine and dentistry, owing to its ability to induce tissue regeneration and bone repair (MAIA; SOUZA, 2009).

Vanat et al. (2012) reported the use of PRP in corneal transplants, wound healing with diabetes mellitus, and bone regeneration. PRP is $100 \%$ biocompatible and safe, and has no risk of infection because it is made from the patient's own plasma (DEROSSI et al., 2009).

Anitua et al. (2006) found that in vitro growth factors for PRP increased the proliferation of human tendon cells and stimulated the production of angiogenic factors, such as vascular endothelial growth factor and hepatocyte growth factor. They also noted that the use of fibrin rich platelet arrays is an effective and safe strategy for accelerating tendon cell proliferation, stimulating type I collagen synthesis, and promoting neovascularization both in vitro and in vivo. Eurides et al. (2015) also observed favorable results with the use of autologous PRP in the gastrocnemius muscle tendons of rabbits.

Rumjantseva and Hoffmeister (2010) reported that a way of assessing the viability of stored platelets is $\mathrm{pH}$ determination. Levels below $\mathrm{pH}$ 6.06.2 are associated with the production of lactate, which tends to accumulate during storage at room temperature. Lactate accumulation leads to a decrease in $\mathrm{pH}$, which is associated with decreased viability of the platelets. In addition, there is the risk of contamination and bacterial growth in platelets stored at room temperature.

For identifying the bacterial agent and determining the antimicrobial susceptibility of the pathogen, it is necessary to inoculate samples on plates of MacConkey agar and blood agar followed by incubation for 24-48 h. Morphological and biochemical tests then allow the presumptive identification of bacterial agents. Additional features that may help with identification include pigment production and odor for both blood agar and MacConkey agar mediums, and the production of hemolysis on blood agar. The final identification of the bacterium is usually based on biochemical and serological tests, while additional tests can be used to identify specific microorganisms (HIRSH et al., 2004; QUINN et al., 2005).

$\mathrm{ApH}<5.0$ favors the growth of fungi. Mutualistic fungi have mandatory associations with other organisms, and are not pathogenic. The saprophytes, which are widely distributed in the environment and are involved in the decomposition of organic matter, can cause opportunistic infections in animals. Fungi are generally isolated in Sabouraud dextrose agar or potato dextrose agar that has a $\mathrm{pH}$ of 5.5 , which inhibits the growth of most bacteria (HIRSH et al., 2004; QUINN et al., 2005). 
Platelets normally present themselves in the idle state (EVERTS et al., 2006) and have multiple receptors responsible for aggregation, e.g., the thromboxane receptor, collagen, and thrombin (BOUDREAUX, 2010). Once activated, platelets change from an elliptical to a round shape, and develop pseudopodia (PIETRZAK; EPPLEY, 2005).

When activated, the live PRP starts the release of pre-synthesized growth factors, which occurs approximately $10 \mathrm{~min}$ after the formation of a clot. This occurs for the first time after activation, leading to an extended release of growth factors stored in the granules, but the platelets continue to synthesize them during their lifetime (SUTTER, 2007).

This study aimed to evaluate the conservation and viability of PRP from New Zealand white rabbit platelets, stored at $4-6{ }^{\circ} \mathrm{C}$ for a period of 30 days. The initial hypothesis was whether such biological material can be stored under the proposed temperature while retaining its characteristics.

\section{Material and Methods}

This study utilized 15 male New Zealand rabbits, weighing $3.5-4.0 \mathrm{~kg}$. The study was approved by the Ethics Committee on the Use of Animals (CEUA/ UFU 070/13) protocol. The animals were first evaluated using a general clinical examination, including measurements of rectal temperature, color of mucous membranes, hydration and heart and respiratory frequency, hemogram (complete blood test), and coprological examination. After being judged suitable to participate in the experiment, the animals were housed in individual cages, allowing a 20-day adjustment period before the beginning of the study. After this period, manual trichotomy and antisepsis occurred with $70 \%$ of the medial aspect of the right thigh being used for femoral artery puncture. Each animal had $18 \mathrm{~mL}$ of blood collected using six tubes of erythrocyte sedimentation (ESR), each containing $0.106 \mathrm{M}$ sodium citrate (ESR tube Sedivette Sarstedt S-Brazil, Santana Parnaíba,
São Paulo, Brazil) and a specific needle (21G, 0.8 x $25 \mathrm{~mm}$, S-Monovette needle Sarstedt Brazil, Santana do Parnaíba, São Paulo, Brazil), to obtain two samples in total. At the end of the collection, a dilution was thus obtained in milliliters of sodium citrate per whole blood, i.e., 0.23:1.0. The 30 samples collected were divided into three equal groups (G1, G2, and G3) for statistical repetition.

Shortly after blood collection, the blood count from each rabbit was analyzed using a veterinary hematology analyzer (Poch 100iVDiff, Sysmex of Brazil Industry and Commerce, São José dos Pinhais, Paraná, Brazil) to determine prior platelet counts. The preparation of PRP was performed under a laminar flow hood (Biological Safety Cabin Class II A1, Filterflux equipment Laboratories, Piracicaba, São Paulo, Brazil). For the preparation of the PRP samples, three tubes, each containing 3.0 $\mathrm{mL}$ of blood, were centrifuged (Centrifuge Fanem Baby I206, Guarulhos, São Paulo, Brazil) for 20 minutes at $2000 \mathrm{rpm}$. After removal of $1.0 \mathrm{~mL}$ of plasma supernatant from each tube, the rest was transferred to a transport tube with a volume of 4.0 $\mathrm{mL}$ and no aspiring leukocyte ring (Labor Import, Osasco, São Paulo, Brazil). The transport tube was subjected to a second spin cycle for 10 minutes at $2000 \mathrm{rpm}$, after, was discarded and supernatant plasma $1.5 \mathrm{~mL}$ and $1.0 \mathrm{~mL}$ remaining plasma was then homogenized pellet the platelets using an automatic pipette (adjustable Micropipette Peguepet, Cotia, São Paulo, Brazil) and the samples stored in $1.8 \mathrm{~mL}$ Eppendorf tubes. Of the total sample volume, 100 $\mu \mathrm{L}$ was used for veterinary hematology analysis to determine platelet counts of the PRP.

Samples from each group were kept in the refrigerator (Consul Refrigerator 300, São Paulo, São Paulo, Brazil) at a temperature between 4 and $6{ }^{\circ} \mathrm{C}$, measured by an internal thermo-hygrometer (KBD6007, China). Only the samples that showed no microbial growth were used for the study. To carry out the microbiological analysis, $50 \mu \mathrm{L}$ of the last supernatant plasma portion was homogenized in a $2.5 \mathrm{~mL}$ brain-heart infusion (BHI) broth (Oxoid, 
Basingstoke, Hampshire, England), which remained in the kiln for $48 \mathrm{~h}$ at $36.0{ }^{\circ} \mathrm{C}$. Seeding was then carried out with a microbiological loop on a Petri plate containing blood agar (Oxoid, Basingstoke, Hampshire, England) and MacConkey agar (Acumedia Manufaturing Inc, Michigan, USA), which was then placed in a kiln at $36.0^{\circ} \mathrm{C}$ for $48 \mathrm{~h}$ and evaluated for the presence of bacterial colonies. The culture of fungi and yeast was performed using the BHI broth, but seeding was performed on potato dextrose agar (Acumedia Manufacturing Inc., Michigan, United States of America), i.e., 1.0 $\mathrm{mL}$ with the addition of $10 \%$ tartaric acid (House of Chemical Industry and Trade, Diadema, São Paulo, Brazil) for each $100 \mathrm{~mL}$ of agar. The plates with yeast samples remained in the oven at $25.0{ }^{\circ} \mathrm{C}$ for five days and were then evaluated for the presence of microorganisms.

Every three days, up to thirty days, of storage, a sample was removed from the refrigerator for evaluation of the bacterial cultures of yeasts and molds, automatic platelet counts, platelet aggregations, and $\mathrm{pH}$. For microbiological assessment, the Eppendorf tube containing the refrigerated sample was opened in a laminar flow hood, $50 \mu \mathrm{L}$ of PRP was harvested, and processed using the same protocols as for the pre-storage.

Once harvested, the amount used for the bacterial and fungal culture PRP was used for analysis of platelet counts with the hematology analyzer. Platelet aggregation was performed using the method described by Aleixo et al. (2011). Briefly, we used $100 \mu \mathrm{L}$ of PRP homogenized in 50 $\mu \mathrm{L}$ of calcium thromboplastin (Soluplastin Wiener Laboratories, Rosario, Argentina), the samples were placed in a water bath at $37^{\circ} \mathrm{C}$, and the aggregation time was measured. Every 20 seconds, the samples were examined for the formation of platelet gels.

Tubes containing the PRP were centrifuged for ten minutes in a micro hematology centrifuge (Fanem Microhemato Centrifuge, Model 2410, Guarulhos, São Paulo, Brazil) and the $\mathrm{pH}$ of the plasma was then measured $(\mathrm{pH}$ meter mPA210, MS Tecnopon Equipment special, Piracicaba, São Paulo, Brazil). The plasma was then diluted in 20 $\mathrm{mL}$ of distilled water, with the dilution established after successive tests with rabbit plasma and distilled water, varying the concentrations until a minimal dilution with water was found where the apparatus could still correctly perform the reading.

To verify any linear relationship between the variables being tested versus time a simple linear regression analysis was performed with the dependent variable attributes being platelet count, mean platelet volume, and $\mathrm{pH}$, and the independent variable being time.

An analysis of variance (ANOVA) was performed for each variable, followed by a Tukey's multiple comparison test, when significant differences were obtained from the ANOVA. Paired sample comparison tests were used to analyze the normality of the differences between the pairs using the Anderson-Darling test. If the differences presented normality, then a paired $t$-test was used to compare the variables present in the blood count to pre-storage and pre-storage compared to poststorage. The nonparametric Wilcoxon test for paired samples was used for the samples that did not show normality.

Analyses were made following the statistical procedures in Banzatto and Kronka (1989), Triola (1999) and Ayres et al. (2007), using a $5 \%$ significance, and we used the Portal Action (2014) that is associated with the program R ( R DEVELOPMENT CORE TEAM, 2014).

\section{Results and Discussion}

No linear relationship with time $(p>0.05)$ was found for the number of platelets in the blood count variable, pre- and post-storage, meaning that there was no influence of time in relation to the number of platelets in the blood count. From the AndersonDarling test (used to evaluate the normality 
of samples), we observed normal errors when comparing the number of platelets in the blood count to the number of platelets in the PRP prestorage $(\mathrm{p}>0.05)$. Therefore, we applied the paired t-test and obtained a statistical difference between these variables $(p<0.05)$. Comparing the number of pre-storage platelets to the number of post-storage platelets, there was normality from the AndersonDarling test $(\mathrm{p}<0.05)$, and statistically significant differences were obtained with the Wilcoxon test $(p<0.05)$. Statistical differences observed in the variables were analyzed for the increased number of platelets post-storage in relation to those in prestorage (Table 1).

Table 1. Means and standard deviations (SD) for the number of platelets in the blood count (BC), and in the preand post-storage for the PRP rabbit samples over the sampling period (days) for this study. Unit of measure: cubic micrometers $\left(\mu \mathrm{m}^{3}\right)$.

\begin{tabular}{crrrrrr}
\hline Days & Mean BC & SD BC & Mean Pre & SD Pre & Mean Post & SD Post \\
\hline 3 & 291000.0 & 96005.2 & 813333.3 & 391566.5 & 842000.0 & 444332.0 \\
6 & 224000.0 & 35679.1 & 613000.0 & 221763.3 & 600666.6 & 266535.8 \\
9 & 209666.6 & 39310.7 & 686000.0 & 247879.0 & 709333.3 & 284106.2 \\
12 & 230333.3 & 40525.7 & 504333.3 & 124957.3 & 398666.6 & 78767.5 \\
15 & 291000.0 & 96005.2 & 1009666.6 & 334049.8 & 1092000.0 & 369048.7 \\
18 & 217333.3 & 9814.9 & 631000.0 & 122049.1 & 683333.3 & 147513.8 \\
21 & 294333.3 & 52974.8 & 961333.3 & 429466.3 & 1027000.0 & 504173.5 \\
24 & 294333.3 & 52974.8 & 953000.0 & 181099.4 & 1014333.3 & 251064.4 \\
27 & 194666.6 & 42122.8 & 574000.0 & 247655.0 & 639666.6 & 306818.0 \\
30 & 195666.6 & 42453.8 & 588000.0 & 94978.9 & 628000.0 & 239025.1 \\
\hline & $244233.3^{\mathrm{a}}$ & 45762.4 & $733366.6^{\mathrm{b}}$ & 411033.1 & $763500.0^{\mathrm{c}}$ & 271894,8 \\
\hline
\end{tabular}

*Different letters in the same line show statistical differences.

There is a reference range for the number of platelets in the PRP, and it is claimed that PRP achieves a platelet concentration three to six times higher than blood (MARX et al., 1998). However, Marx (2001) mentioned that PRP is more effective when the concentration of platelets are around 1 000000 platelets $\mathrm{L}^{-1}$ in a standard $6.0 \mathrm{~mL}$ volume of plasma. Consistent findings were observed in this study, where platelet concentrations were three times higher than the platelets found in whole blood in a $1.0 \mathrm{~mL}$ volume of plasma.

Regarding the increase in the number of platelets observed in the samples after storage, Comar et al. (2009) stated that the presence of red cell fragments, cytoplasmic leukemic cells, blood lipids, bacteria, yeast and microcytes with volumes close to the platelets, can all be counted by hematology analyzers, leading to a false increased platelet count.
In this experiment, an increase in platelet counts was noted in samples after storage, possibly owing to fragmentation of other plasma cells such as white cells and erythrocytes.

The mean platelet volume (MPV) variable in the blood count, pre- and post-storage, showed no linear relationship with time $(p>0.05)$, implying no influence of time on the MPV variable. When comparing the MPV hemogram to the MPV prestorage, and the MPV pre-storage to the MPV poststorage, using the Anderson-Darling normality test, the results were normal $(p>0.05)$. After application of the paired $t$-test, significant differences $(\mathrm{p}<$ 0.05) were found for both these comparisons. A significant increase in post-storage MPV was also found, independent of the number of days (Table 2). 
Table 2. Means and standard deviations (SD) for the mean platelet volume (MPV) in the blood count (BC), and in the pre- and post-storage for the PRP rabbit samples over the sampling period (days) for this study. Unit of measure: femtoliters (fL).

\begin{tabular}{ccccccc}
\hline Days & $\begin{array}{c}\text { Mean MPV } \\
\text { BC }\end{array}$ & SD MPV BC & $\begin{array}{c}\text { Mean MPV } \\
\text { Pre }\end{array}$ & SD MPV Pre & $\begin{array}{c}\text { Mean MPV } \\
\text { Post }\end{array}$ & SD MPV Post \\
\hline 3 & 6.43 & 0.25 & 6.47 & 0.06 & 9.30 & 0.26 \\
6 & 6.80 & 0.43 & 6.73 & 0.30 & 10.70 & 0.46 \\
9 & 6.83 & 0.40 & 6.63 & 0.21 & 11.03 & 0.66 \\
12 & 6.40 & 0.26 & 6.66 & 0.38 & 9.90 & 0.78 \\
15 & 6.43 & 0.25 & 6.83 & 0.35 & 10.70 & 1.15 \\
18 & 6.73 & 1.15 & 6.66 & 1.01 & 10.23 & 1.44 \\
21 & 6.73 & 0.25 & 7.16 & 0.51 & 11.13 & 1.03 \\
24 & 6.73 & 0.25 & 7.30 & 0.26 & 10.90 & 1.15 \\
27 & 6.60 & 0.20 & 7.03 & 0.25 & 9.03 & 0.65 \\
30 & 6.26 & 0.76 & 6.46 & 0.97 & 9.23 & 0.85 \\
\hline
\end{tabular}

*Different letters in the same line show statistical differences.

The MPV is a biological variable that determines the function of platelets and platelet activity (BATH et al., 2004). Factors such as the technology used, variable pre-analytical effects of anticoagulants, temperature, and time of storage of the material all cause interferences when determining the MPV (GULATI et al., 2002; VOGELAAR et al., 2002). Using sodium citrate as an anticoagulant retains the platelets with a spherical shape, which could increase the MPV (MACEY et al., 2002; GREISENEGGER et al., 2004). Bulky and aggregate platelets have higher MPV values and decreased counts (RACCHI; RAPEZZI, 2001; BAIN; PATH, 2005). MPV values increase in a time-dependent way, due to platelet swelling, however, the size of the platelet increase is less than approximately $0.5 \mathrm{fL}$ when the analysis is performed within two hours after venipuncture. The elevation of MPV observed in this study corroborates with evidence from Greisenegger et al. (2004), who observed an increase in the poststorage compared to the pre-storage MPV, which is believed to be caused by cellular edema related to the observation period.

For plasma $\mathrm{pH}$ pre- and post-storage, there was no linear relationship as a function of time $(\mathrm{p}>$ 0.05). The ANOVA of each variable for the average multiple comparisons showed a statistical difference $(\mathrm{p}<0.05)$ for the post-storage samples. However, the results showed no statistical difference for the poststorage $\mathrm{pH}$ in the comparison between the different periods, i.e., 30 and 6 days, 30 and 24 days, and 30 and 27 days. The Anderson-Darling test found normality when comparing the $\mathrm{pH}$ of samples preand post-storage $(\mathrm{p}>0.05)$ and the paired t-test showed a statistical difference $(\mathrm{p}<0.05)$. The $\mathrm{pH}$ results after storage showed a slight alkalizing value (Table 3).

Metabolic products, such as lactate, may accumulate during storage at room temperature causing a drop in pH (MURPHY; GARDNER, 1971). $\mathrm{pH}$ levels below 6.0-6.2 (MURPHY et al., 1994) or up to 6.5 (PISCIOTTO et al., 1991) are associated with decreased platelet viability. At 4 ${ }^{\circ} \mathrm{C}$, it has been found that lactate accumulation is minimal, and does not decrease the $\mathrm{pH}$ (SLICHTER, 1981). Studies have shown that platelet samples that were stored at $4{ }^{\circ} \mathrm{C}$ showed better $\mathrm{pH}$ stability, a reduced rate of glycolysis, and better response when stimulated by epinephrine or collagen, than platelets stored at room temperature; it has also been suggested that refrigerated platelets have better cell stability (RUMJANTSEVA; HOFFMEISTER, 
2010). The development of materials and bags for the storage of platelets, such as containers that promote the exchange of oxygen and carbon dioxide, and greater platelet storage volumes to stabilize the $\mathrm{pH}$, would result in better viability of the platelets (MURPHY, 2002). The $\mathrm{pH}$ of the PRP samples did not reach levels that would cause a decrease in platelet viability. The statistical differences found among the samples stored between 30 and 6 days, 30 and 24 days, and 30 and 27 days were due to a significant decrease of the $\mathrm{pH}$ (7.35) in the 30-day samples, which may be explained by the anaerobic conditions of the medium causing possible lactate production during this period.

Table 3. Means and standard deviations (SD) for $\mathrm{pH}$ pre- and post-storage in PRP rabbit samples over the sampling period (days) for this study.

\begin{tabular}{ccccc}
\hline Days & Mean $\mathrm{pH}$ Pre & SD pH Pre & Mean $\mathrm{pH}$ Post & SD pH Post \\
\hline 3 & 7.51 & 0.04 & 7.62 & 0.22 \\
6 & 7.65 & 0.13 & 7.94 & 0.07 \\
9 & 7.62 & 0.14 & 7.75 & 0.09 \\
12 & 7.57 & 0.10 & 7.76 & 0.16 \\
15 & 7.51 & 0.04 & 7.79 & 0.23 \\
18 & 7.57 & 0.07 & 7.76 & 0.16 \\
21 & 7.51 & 0.08 & 7.69 & 0.03 \\
24 & 7.51 & 0.08 & 7.86 & 0.17 \\
27 & 7.46 & 0.08 & 7.99 & 0.30 \\
30 & 7.54 & 0.12 & 7.35 & 0.07 \\
\hline
\end{tabular}

*Different letters in the same line show statistical differences.

Within twenty seconds after addition of calcium thromboplastin to the samples, platelet aggregation occurred in all samples (G1, G2, and G3, Figure 1 - A). The type and concentration of calcium thromboplastin used for platelet activation was effective, as indicated by Aleixo et al. (2011). Nunes Filho et al. (2007) used 10\% calcium chloride for the activation of platelets in PRP from dogs, which was also successful. However, according to Yamada et al. (2012) calcium chloride is a weak platelet activator, with its main function being to antagonize the anticoagulant used, allowing the formation of gel. The activation, for example by thrombin, causes a change in the shape of the platelets, and subsequently, they develop pseudopodia, which promotes platelet aggregation and the subsequent release of granules containing growth factors through the open canalicular system (EVERTS et al., 2006). According to Wallace et al. (1993), in order for platelets to be considered clinically effective, they must exercise a clotting function, i.e., prevent or stop bleeding. It was reported by Murphy and Gardner (1971) that platelets are metabolically active at room temperature, which does not occur in platelets stored at $4{ }^{\circ} \mathrm{C}$, for at lower temperatures beta granules released to the storage medium does not occur. In this study, platelet aggregation occurred within the same time interval, for both pre- and post-stored samples, as well as for an independent evaluation period, which suggests that PRP remained intact and viable during the entire study period. Platelet degranulation occurs only after aggregation/activation; therefore, it is believed that the PRP remained within the platelet granules. This is important for the use of platelets in restorative and reconstructive surgery. 
Figure 1. Platelet-rich plasma from New Zealand rabbits. A: Platelet aggregation gel from a platelet-rich plasma sample (G2) obtained after the addition of calcium thromboplastin on the 27th refrigerated storage day. B: Fungal colonies (red arrows) growing on potato dextrose agar in a platelet-rich plasma sample (G1) after 21 days of refrigeration $\left(4-6{ }^{\circ} \mathrm{C}\right)$.

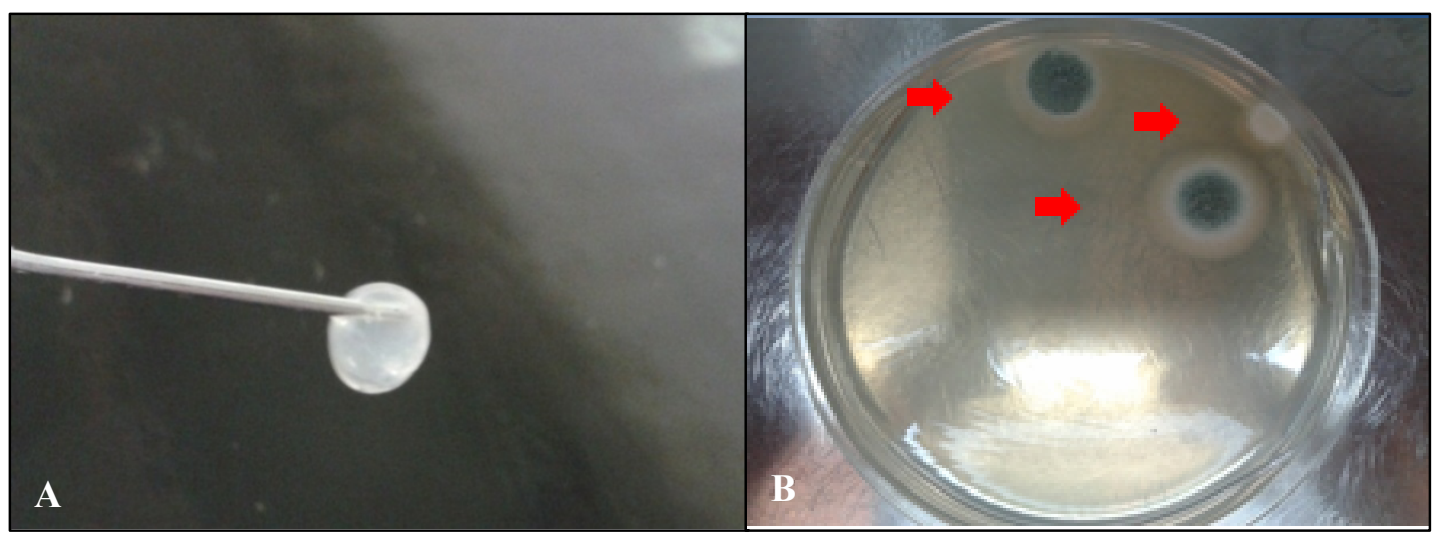

No bacterial or yeast growth was observed in any of the samples, regardless of the storage period, but growth of mold was observed in samples after 21 days in the G1 and G3 groups (Figure $1-\mathrm{B}$ ). Previous studies investigating the concomitant risk of bacterial growth in platelets stored at room temperature suggest that storage is limited to five days (RUMJANTSEVA; HOFFMEISTER, 2010). The routine isolation of many pathogens involves inoculation of blood agar and MacConkey agar plates, followed by incubation for 24-48 h. These methods are used to identify bacteria through the production of pigments and odors in both blood agar and MacConkey agar, and the production of hemolysis on blood agar. Fungi are generally isolated in Sabouraud dextrose agar or potato dextrose agar, which has low $\mathrm{pH}$ that inhibits the growth of most bacteria (HIRSH et al., 2004; QUINN et al., 2005). The preparation of potato dextrose agar involves adding $1.0 \mathrm{~mL}$ of $10 \%$ tartaric acid to $100 \mathrm{~mL}$ of each medium, and acidifying to ensure consequent inhibition of bacterial growth at the end of the incubation has a pH of 4.0-4.5 (GAVA, 2002). Although mold growth occurred in the samples in this present study after 21 days of storage in G1 and G3, no macroscopic or color changes were observed in the samples. The $\mathrm{pH}$ of the samples from G1 and G3 was 7.66 and 7.73, respectively, which are $\mathrm{pH}$ values at which fungal growth does not occur (QUINN et al., 2005). Therefore, it is assumed that contamination with fungal spores occurred during storage, and mold growth occurred when seeded in medium with favorable $\mathrm{pH}$. It was found that the Eppendorf micro tubes prevented bacterial contamination of samples and yeasts during storage.

In conclusion, the findings of this study demonstrated that the PRP in New Zealand male rabbits can be stored in $4-6{ }^{\circ} \mathrm{C}$ refrigeration for up to 18 days, and can still maintain the number of platelets, with no significant $\mathrm{pH}$ changes or bacterial or fungal contamination.

\section{Acknowledgements}

The authors would like to acknowledge the Coordination of Higher Education Personnel Training (Coordenação Aperfeiçoamento de Pessoal de Ensino Superior - CAPES) and the National Council for Scientific and Technological Development (Conselho Nacional de Desenvolvimento Científico e Tecnológico - CNPq) for the master's scholarships, research productivity, and scientific research needed to complete this research. 


\section{References}

ACTION. Portal Action. São Carlos: Portal Action, 2014. Disponível em: <http://www.portalaction.com. br>. Acesso em: 23 jul. 2014.

ALEIXO, G. A. S.; COELHO, M. C. O. C.; TEIXEIRA, M. N.; MESQUITA, E. P.; OLIVEIRA, F. F.; ZUBIETA, L. M. V.; ALMEIDA, T. L. C.; GUIMARÃES, A. L. N.; MAIAL, F. C.; ZACARIAS, T. F. L.; SANTOS, S. M. L. G.; LIMA, C. P. S. Comparação entre dois protocolos para obtenção de plasma rico em plaquetas, em cães. Arquivo Brasileiro de Medicina Veterinária e Zootecnia, Belo Horizonte, v. 63, n. 3, p. 567-573, 2011.

ANITUA, E.; SÁNCHEZ, M.; NURDEN, A. T.; ZALDUENDO, M.; FUENTE, M.; ORIVE, G.; AZOFRA, J.; ANDÍA, I. Autologous fibrin matrices: A potential source of biological mediators that modulate tendon cell activities. Journal of Biomedical Materials Research Part A, Hoboken, v. 77, n. 2, p. 285-293, 2006.

AYRES, M.; AYRES JÚNIOR, M.; AYRES, D. L.; SANTOS, A. A. BIOESTAT 5. 0: aplicações estatísticas nas áreas das ciências biológicas e médicas. Belém: Ong Mamiraua, 2007. 364 p.

BAIN, B. J.; PATH, F. R. C. Diagnosis from the blood smear. New England Journal of Medicine, Waltham, v. 353, n. 5, p. 498-507, 2005.

BANZATTO, D. A.; KRONKA, S. N. Experimentação agrícola. Jaboticabal: Funep. 1989. 237 p.

BATH, P.; ALGERT, C.; CHAPMAN, N.; NEAL, B. Association of mean platelet volume with risk of stroke among 3,134 individuals with history of cerebrovascular disease. Stroke, Dallas, v. 35, n. 3, p. 622-626, 2004.

BOUDREAUX, M. K. Platelets. In: WEISS, D. J.; WARDROP, K. J. Schalm's veterinary hematology. $6^{\text {th }}$ ed. Iowa: Wiley-Blackwell, 2010. cap. 6, p. 561-568.

COMAR, S. R.; DANCHURA, H. S. M.; SILVA, P. H. Contagem de plaquetas: avaliação de metodologias manuais e aplicação na rotina laboratorial. Revista Brasileira de Hematologia e Hemoterapia, Santos, v. 31, n. 6, p. 431-436, 2009.

DEROSSI, R.; COELHO, A. C. A. O.; MELLO, G. S.; FRAZÍLIO, F. O.; LEAL, C. R. B.; FACCO, G. G.; BRUM, K. B. Effects of platelet-rich plasma gel on skin healing in surgical wound in horses. Acta Cirúrgica Brasileira, São Paulo, v. 24, n. 4, p. 276-281, 2009.

EURIDES, D.; GUIMARÃES, C. P. A.; BELETTI, M. E.; MUNDIM, A. V.; SOUZA, L. A.; GONÇALVES, G. F.; EURIDES, G. P. Plasma rico em plaquetas autólogas na cicatrização do tendão do músculo gastrocnêmio de coelhos. Brazilian Journal of Veterinary Research and Animal Science, São Paulo, v. 52, n. 1, p. 48-56, 2015.

EVERTS, P. A. M.; KNAPE, J. T. A.; WEIBRICH, G.; SCHÖNBERGER, J. P. A. M.; HOFFMANN, J.; OVERDEVEST, E. P.; BOX, H. A. M.; ZUNDERT, A. Platelet-rich plasma and platelet gel: a review. The Journal of the American Society of Extra-corporeal Technology, Richmond, v. 38, n. 2, p. 174-187, 2006.

GAVA, M. A. Desempenho de diferentes meios de cultura utilizados na avaliação de fungos presentes em ambientes de produção de alimentos. 2002. Dissertação (Mestrado em Ciências) - Escola Superior de Agricultura Luiz de Queiroz. Universidade de São Paulo, São Paulo.

GREISENEGGER, S.; ENDLER, G.; HSIEH, K.; TENTSCHERT, S.; MANNHALTER, C. LALOUSCHEK, W. Is elevated mean platelet volume associated with a worse outcome in patients with acute ischemic cerebrovascular events? Stroke, Dallas, v. 35, n. 7, p. 1688-1691, 2004.

GULATI, G. L.; HYLAND, L. J.; KOCHER, W.; SCHWARTING, R. Changes in automated complete blood cell count and differential leukocyte count results induced by storage of blood at room temperature. Archives of Pathology and Laboratory Medicine, Chicago, v. 126, n. 3, p. 336-42, 2002.

HIRSH, D. G.; ZEE, Y. C.; CASTRO, A. E. Laboratory diagnosis. In: HIRSH, D.G.; MACLACHLAN, N. J.; WALKER, R. L. Veterinary microbiology. $2^{\text {th }}$ ed. Iowa: Blackwell Publishing, 2004. p. 15-25.

MACEY, M.; AZAM, U.; McCARTHY, D.; WEBB, L.; CHAPMAN, E. S.; OKRONGLY, D. ZELMANOVIC, D.; NEWLAND, A. Evaluation of the anticoagulants EDTA and citrate, theophylline, adenosine and dipyridamole (CTAD) for assessing platelet activation on the Advia 120 hematology system. Clinical Chemistry, Baltimore, v. 48, n. 6, p. 891-899, 2002.

MAIA, L.; SOUZA, M. V. Componentes ricos em plaquetas na reparação de afecções tendo-ligamentosas e osteo-articulares em animais. Ciência Rural, Santa Maria, v. 39, n. 4, p. 1279-1286, 2009.

MARX, R. E. Platelet-rich plasma (PRP): what is PRP and what is not PRP? Implant Dentistry, Baltimore, v. 10, n. 4, p. 225-228, 2001.

MARX, R. E.; CARLSON, E. R.; EICHSTAEDT, R. M.; SCHIMMELE, S. R.; STRAUSS, J. E.; GEORGEFF, K. R. Platelet-rich plasma: growth factor enhancement for bone grafts. Oral Surgery, Oral Medicine, Oral Pathology, Oral Radiology, Saint Louis, v. 85, n. 6, p. 638-646, 1998. 
MURPHY, S. What's so bad about old platelets? Transfusion, Arlington, v. 42, n. 7, p. 809-811, 2002.

MURPHY, S.; GARDNER, F. Effect of storage temperature on maintenance of platelet viabilitydeleterious effect of refrigerated storage. New England Journal of Medicine, Waltham, v. 280, n. 20, p. 10941098, 1971.

MURPHY, S.; REBULLA, P.; BERTOLINI, F.; HOLME, S.; MOROFF, G.; SNYDER, E.; STROMBERG, R. In vitro assessment of the quality of stored platelet concentrates. The BEST (biomedical excellence for safer transfusion) task force of the international society of blood transfusion. Transfusion Medicine Reviews, v. 8, n. 1, p. 29-36, 1994.

NUNES FILHO, D. P.; LUPPINO, F.; YAEDÚ, R. Y. F.; CARVALHO, P. S. P. Avaliação microscópica da ação do osso autógeno associado ou não ao PRP em cavidades ósseas de cães. Implant News, São Paulo, v. 4, n. 3, p. 263-269, 2007.

PIETRZAK, W. S.; EPPLEY, B. L. Platelet rich plasma: biology and new technology. The Journal of Craniofacial Surgery, Boston, v. 16, n. 6, p. 1043-1054, 2005.

PISCIOTTO, P. T.; SNYDER, E. L.; NAPYCHANK, P. A.; HOPFER, S. M. In vitro characteristics volume reduced platelet concentrate stored in syringes. Transfusion, Arlington, v. 31, n. 5, p. 404-408, 1991.

QUINN, P. J.; MARKEY, B. K.; CARTER, M. E.; DONNELLY, W. J.; LEONARD, F. C. Microbiologia veterinária e doenças infecciosas. Porto Alegre: Artmed. 2005. 512 p.

R DEVELOPMENT CORE TEAM - R. A language and environment for statistical compunting. [S. 1]: R Development, 2014.

RACCHI, O.; RAPEZZI, D. Megathrombocytes and spurious thrombocytopenia. European Journal of Haematology, Copenhagen, v. 66, n. 2, p. 140-141, 2001.
RUMJANTSEVA, V.; HOFFMEISTER, K. M. Novel and unexpected clearance mechanisms for cold platelets. Transfusion and Apheresis Science, Ottawa, v. 42, n. 1, p. 63-70, 2010.

SLICHTER, S. J. In vitro measurements of platelet concentrates stored at 4 and $22^{\circ} \mathrm{C}$ : correlation with posttransfusion platelet viability and function. Vox Sanguinis: International Journal of Blood Transfusion and Immunohaematology, Basel, v. 40, n. 1, p. 72-86, 1981.

SUTTER, W. W. Autologous cell-based therapy for tendon and ligament injuries. Clinical Techniques in Equine Practice, Ocala, v. 6, n. 3, p. 198-208, 2007.

TRIOLA, M. F. Introdução à estatística. 7. ed. Rio de Janeiro: LTC Editora, 1999. 410 p.

VANAT, N.; MEDEIROS, T. N. S.; BALARIN, M. R. S.; PEREIRA, P. M.; BIASI, F. Modificação de técnica de preparo do plasma rico em plaquetas em cães. Semina: Ciências Agrárias, Londrina, v. 33, n. 1, p. 313-322, 2012.

VOGELAAR, S. A.; POSTHUMA, D.; BOOMSMA, D.; KLUFT, C. Blood stability at room temperature for counting red and white blood cells and platelets. Vascular Pharmacology, New York, v. 39, n. 3, p. 123-125, 2002.

WALLACE, E. L.; SURGENOR, D. M.; HAO, H. S.; AN, J.; CHAMPMAN, R. H.; CHURCHILL, W. H. Collection and transfusion of blood and blood components in the United States, 1989. Transfusion, Malden, v. 33, n. 2, p. 139-144, 1993.

YAMADA, A. L. M.; CARVALHO, A. M.; OLIVEIRA, P. G. G.; FELISBINO, S. L.; QUEIROZ, D. L.; WATANABE, M. J.; HUSSNI, C. A.; ALVES, A. L. G. Plasma rico em plaquetas no tratamento de lesões condrais articulares induzidas experimentalmente em equinos: avaliação clínica, macroscópica, histológica e histoquímica. Arquivo Brasileiro de Medicina Veterinária e Zootecnia, Belo Horizonte, v. 64, n. 2, p. 323-332, 2012. 